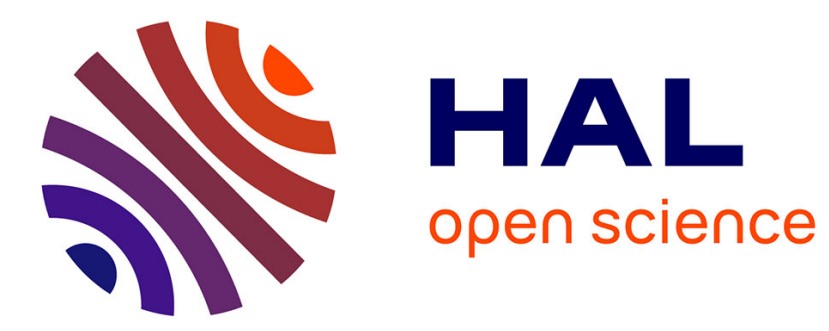

\title{
Lagos and the invention of juvenile delinquency in Nigeria
}

Laurent Fourchard

\section{To cite this version:}

Laurent Fourchard. Lagos and the invention of juvenile delinquency in Nigeria. Journal of African History, 2006, 47 (1), pp.115-137. 10.1017/S0021853705001660 . halshs-00238541

\section{HAL Id: halshs-00238541 https://shs.hal.science/halshs-00238541}

Submitted on 4 Feb 2008

HAL is a multi-disciplinary open access archive for the deposit and dissemination of scientific research documents, whether they are published or not. The documents may come from teaching and research institutions in France or abroad, or from public or private research centers.
L'archive ouverte pluridisciplinaire HAL, est destinée au dépôt et à la diffusion de documents scientifiques de niveau recherche, publiés ou non, émanant des établissements d'enseignement et de recherche français ou étrangers, des laboratoires publics ou privés. 


\title{
LAGOS A N THE I N VENTION OF J U VEN I L D E L I N Q UEN C Y I N N I GER I A, 1920-60*
}

\author{
BY LAURENT FOURCHARD \\ Fondation Nationale des Sciences Politiques, Centre d'Étude d'Afrique \\ Noire, Bordeaux
}

\begin{abstract}
This paper seeks to trace the origins of offences by youths as a distinct social concern in Lagos and examines the categorization of a group, the 'juvenile delinquent', by colonial administrators and welfare officers. While organized pickpocketing and prostitution by young people emerged as an issue in Nigerian newspapers in the I920s, it was largely ignored by local administrators until the appointment, in I94I, of the first Social Welfare Officer. This led to the implementation of new administrative and judiciary machinery which combined two processes: it legislated 'juvenile delinquency' into existence as a clearly identifiable social problem; and criminalized a large portion of urban youth, especially female hawkers. The combination of these processes constitutes what can be called the invention of juvenile delinquency in Nigeria.
\end{abstract}

KEY WORDS: Nigeria, colonial, crime, gender, youth, urban, welfare.

I $\mathrm{T}$ was the Second World War that made juvenile delinquency a 'problem' in Africa.' 'John Iliffe does not consider 'juvenile delinquency' as new in the I940s, but suggests that it was becoming a central issue, an obsession of the 'compassionate period', after I 945. His argument establishes an important difference between the historical presence of young offenders in Africa and its late discovery by colonial officers. Our knowledge of urban youth crime dates back to the Second World War when social welfare services were set up in the British and French colonies and international institutions started to consider juvenile delinquency as one of the major issues of urbanization in Africa. ${ }^{2}$ Since the r 950 s child destitution and the phenomenon of so-called 'street children' have received continuing but unequal attention. ${ }^{3}$ The literature, mainly devoted to contemporary analysis, has been complemented for the past fifteen years by historical research. ${ }^{4}$

* I want to thank Richard Waller, Ayodeji Olukoju and the two anonymous readers of Fournal of African History for their comments on an early version of this paper.

${ }^{1}$ John Iliffe, The African Poor: A History (Cambridge, i987), i 87.

${ }^{2}$ Ibid. 1 85-7; Serge Nédélec, 'Etat et délinquance juvénile au Sénégal contemporain', in F. Bernault (ed.) Enfermement, prison et châtiments en Afrique : du I9 ${ }^{\text {ème }}$ siècle à nos jours (Paris, I 999), 4I3.

${ }^{3}$ Daniel Poitou et René Collignon, Délinquance juvénile et marginalité des jeunes en milieu urbain d'Afrique noire. Eléments de bibliographie (I950-I984) (Paris, I985).

${ }^{4}$ Andrew Burton, 'Urchins, loafers and the cult of the cowboys: urbanisation and delinquency in Dar es Salam, I9 19-6I', Fournal of African History, 42 (2001), I 99-2 I6; Clive Glaser, Bo Tsotsi: The Youth Gangs of Soweto, 1935-I976 (Oxford, 2001); Simon Heap, 'Jaguda Boys: pickpocketing in Ibadan, I930-60', Urban History, 24 ( 1997), 324-43; Yves Marguerat, "'Les Smallvi ne sont pas des Gevouvi”: histoire de la 
This article is based on Nigerian newspapers and administrative reports. ${ }^{5}$ Both sources represent the perspective of older people: they do not express the voices of the young, for these require an investigation of other sources. In focusing on the Lagos case, I would like to trace the origins of offences by youths as a distinct social concern and to demonstrate how some children and youths came to be considered as criminal from the r 940 onward. The late discovery of juvenile offenders and the criminalization of some African youth practices constitute what I call the invention of juvenile delinquency. This process is quite similar to what occurred in Britain at the beginning of the nineteenth century when British reformers invented the notion of the 'Delinquent Child'. ${ }^{6}$ The development of an administrative and judiciary machinery legislated 'juvenile delinquency' into existence : henceforth clearly identifiable as a social problem. Such a process was engineered in Lagos by the new Welfare Service set up during the Second World War. Lagos was not, however, unique, and specific judicial machinery for the 'treatment of juvenile offenders' was also established in the French, Belgian, British and Portuguese empires in the r940s and I950s. ${ }^{7}$

\section{URBANIZATION AND POVERTY IN COLONIAL LAGOS}

The original site of Lagos is an island located between the sea and the lagoon that gave Lagos its name in Portuguese. At the beginning of the nineteenth century, Lagos became the main slave port along the Slave Coast but it was still a small town when the British annexed it in $\mathrm{r} 86 \mathrm{I} .{ }^{8}$ During the second half of the nineteenth century, the population increased slowly - from 25,000 in I 866 to 38,387 in I90 I (see Table I). ${ }^{9}$ The progressive export substitution of palm oil for slaves and the consolidation of the position of Lagos on the

marginalité juvénile à Lomé', in Y. Marguerat et D. Poitou (sous la dir.), A l'écoute des enfants de la rue en Afrique noire (Paris, I994), 248-80; Ibrahima Thioub, 'Marginalité juvénile et enfermement à l'époque coloniale: les premières écoles pénitentiaires du Sénégal, i 888-1927', in Bernault (ed.), Enfermement, 205-26. For a general overview of urban crime in colonial and postcolonial West Africa see Laurent Fourchard and Isaac O. Albert (eds.), Security, Crime and Segregation in West African Cities since the Nineteenth Century (Paris, 2003).

5 The following newspapers have been consulted: Nigerian Pioneer from 1920 to I930, West African Pilot from I 937 to I960, Nigerian Daily Times from 1930 to 1960. Official correspondence and Social Welfare Service reports can be found in the Colonial Office (CO) files in the Public Record Office (PRO), now British National Archives, in London and in the three federal archive centres in Nigeria: the National Archives, Ibadan (NAI); the National Archives, Enugu (NAE), the National Archives, Kaduna (NAK); and in the Calabar Provincial Office (CPO). For assistance in the Nigerian archives, I thank Saheed Aderinto.

${ }^{6} \mathrm{H}$. Hendrick, 'Constructions and reconstructions of British childhood: an interpretative survey, I80o to the present', in A. James and A. Proat (eds.), Constructing and Reconstructing Childhood (Basingstoke, I990), 40-5.

${ }^{7}$ See for instance, the Conference on the Treatment of Offenders (Juvenile Delinquents) in Kampala, I956, organized by the Commission of Technical Cooperation in Africa, South of the Sahara.

${ }^{8}$ Robin Law, 'Trade and politics behind the Slave Coast: the Lagoon traffic and the rise of Lagos, I 500-I 800', Fournal of African History, 24 ( I 983), 32 I-48.

9 The various censuses made by the British in Lagos were based on house to house estimations that gave only rough estimates of the population. 
Table I. Population growth of selected Nigerian cities (I866-I963)

\begin{tabular}{|c|c|c|c|c|c|c|c|c|}
\hline & I 866 & I 89 I & I $90 \mathrm{I}$ & I9I I & I 92 I & I 93 I & I $95 \mathrm{I}-3$ & I 960-3 \\
\hline Lagos & $25, \circ 83$ & 32,508 & 38,387 & 73,766 & 99,700 & I 26,000 & 230,250 & 665,246 \\
\hline Ibadan & 100,000 & I $20,000^{a}$ & & I 75, ০00 & 238,000 & 387,000 & 459,000 & 600,000 \\
\hline Kano & $30,000^{a}$ & & & & & 96,000 & I 27,205 & 400,000 \\
\hline
\end{tabular}

a Rough estimate from Alvan Millson, 'The Yorubas country, West Africa', Proceedings of the Royal Geographical Society, I3 (I891), 583.

b Rough estimate for I 824 from D. Denham, H. Clapperton and N. Oudney, Narrative of Travels and Discoveries in Northern and Central Africa in the Years I822, I823 and I824 (London, I828).

Sources: Mabogunje, Urbanization, 327-9, Eva Krapf-Askari, Yoruba Towns and Cities: An Enquiry into the Nature of Urban Social Phenomena (Oxford, I969), 35.

West African coast attracted European merchants, ex-slaves from Brazil and Cuba, slaves freed by the British on the coast and refugees from the interior. However, the high death rate at the close of the nineteenth century (40 per I,, 00 ) limited the rapid expansion of the city. ${ }^{10}$ All the inhabitants, including Europeans, were living on the same place in Lagos Island.

From the I 900 s onward, the progressive concentration of administrative, commercial and industrial activities in Lagos, combined with a permanent influx of migrants and improved health conditions, increased the population dramatically. ${ }^{11}$ At Independence in 1960 , Lagos had become the largest city in Nigeria and West Africa (665,000 inhabitants in 1963). Some scholars have suggested that the rate of immigration decreased between the wars as the pace of economic development slowed, ${ }^{12}$ and more thorough research on the matter has demonstrated that without migration the population of Lagos would have decreased after the First World War due to the influenza epidemic of I9I 8 and the bubonic plague outbreaks between I 924 and I $928 .{ }^{13}$ The very high percentage of the population born outside Lagos (59 per cent in I93I, 63 per cent in I950) indicates that, almost since the I920s, migrants have contributed significantly to the growth of the city (see Fig. I). ${ }^{\mathbf{1 4}}$

The major regional sources of immigrants were Abeokuta, Ijebu and Oyo Provinces. The most important factor stimulating immigration to Lagos was the widening gap in employment opportunities between Lagos and the rest of the country. ${ }^{15}$ Largely due to the inflow of migrants, Lagos remained a

10 Akin Mabogunje, Urbanisation in Nigeria (New York, I968), 259.

${ }^{11}$ In I9I4 the Protectorate of Northern Nigeria was amalgamated with the Southern Protectorate to form Nigeria with Lagos as capital.

12 Pauline H. Baker, Urbanization and Political Change: The Politics of Lagos, I9I7-I967 (Berkeley, I974), 32; Margaret Peil, Lagos: The City Is the People (London, I99I), I 9 .

${ }^{13}$ Ayodeji Olukoju, 'Population pressure, housing and sanitation in West Africa's premier port-city: Lagos, I900-1939', Fournal of the Australian Association for Maritime History, i 5 (1993), 92-3.

${ }^{14}$ Olukoju, 'Population', 93; Mabogunje, Urbanisation, 264.

15 Mabogunje, Urbanisation, 26I. 


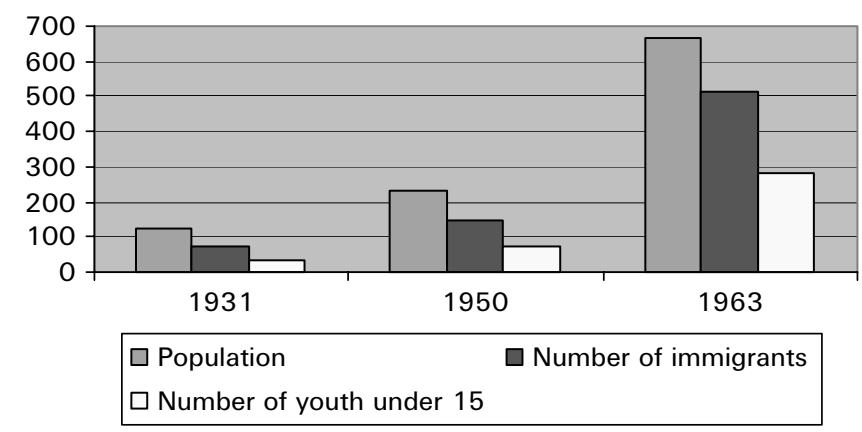

Fig. I. Population growth, immigrants and youth in Lagos, I93 I-63 (in thousands). Sources: Mabogunje, Urbanization, 262; Baker, Urbanization, 33, 40.

predominantly male and very youthful city throughout the period. ${ }^{16}$ The age composition shows an increasing proportion in the under-thirty age group, climbing from 62 per cent in $192 \mathrm{I}$ to 78 per cent in 1972 . Within this population the proportion of children under i 5 years of age rose from 27 per cent in I93 I to 43 per cent in 1963 (Fig. I) ${ }^{17}$

A number of factors have been advanced to explain the development of delinquent behaviour among the youth. The most common explanation advanced by the colonial administration centred on the breakdown of tribal life and family ties. A comprehensive report compiled in 1948 stressed that a 'high incidence and constant increase of juvenile delinquency is reported from areas where the decline of the tribal system is fairly advanced and where this decline has its counterpart in the simultaneous growth of urban and industrial centres' ${ }^{18}$ 'This, it was agreed, was the case in Nigeria, Kenya and Northern Rhodesia, where juvenile delinquency appeared to be a specifically urban phenomenon.

I have indicated elsewhere that the lack of native authority institutions, of any form of social organization and of any indigenous or colonial police force were important reasons why criminality was developing in two migrant settlements on the outskirts of Ibadan and Lagos respectively before the Second World War. ${ }^{19}$ Moreover as the value of urban land increased, precolonial patterns of land tenure, generally based on lineage and family, changed progressively to a new colonial pattern based on rent. ${ }^{20}$ In Lagos and other Nigerian cities, the Yoruba family compound broke down into smaller residential units rented out to migrants. ${ }^{21} \mathrm{With}$ renting, control over tenants and social control over the ward tended to diminish. To keep control over their communities both indigenous dwellers and migrant settlers created

${ }^{16}$ Ibid. 265. ${ }^{17}$ Baker, Urbanization, 40; Peil, Lagos, 22.

${ }^{18}$ NAI, Oyo Prof, I352, Juvenile Delinquency and its treatment, I 948.

19 L. Fourchard, 'Urban poverty, urban crime and crime control: the Lagos and Ibadan cases, 1929-1945', in S. Salm and T. Falola (eds.), African Urban Spaces in Historical Perspective (Rochester NY, 2005), 29 I-3 I 9.

${ }^{20}$ Laurent Fourchard, 'De la résidence lignagère à la rente immobilière, cours et compounds en AOF et au Nigeria', Le mouvement social, 2 I 4 (2003), 47-63.

${ }_{21}$ Mabogunje, Urbanisation, 226; Peter Marris, Family and Social Change in an African City: A Study of Rehousing in Lagos (Northwestern, 1962), 20-5. 
political, religious, ethnic or neighbourhood associations. ${ }^{22}$ It is obvious however that most local unions were too 'loosely organised and short of funds to aid more than a small minority of the poor'. ${ }^{23}$ Social workers also pointed lack of parental control, family disintegration and the harsh discipline in local schools as factors pushing so many children on to the street (see below). According to Peter Marris 'much of the delinquency of children in Lagos is a reaction to the severity and lack of understanding of their guardians' ${ }^{24}$

Poverty was, however, the root cause of delinquency. Employment was the main attraction for youth migrants from the country and, if trade or administrative and industrial opportunities gave rise to a rich African elite, poverty had also been a permanent part of the port city's history. According to Iliffe, towns pioneered the transformation of the nature of poverty in Africa when, at the end of the nineteenth century, poverty took new forms dominated by unemployment, proletarianization, prostitution and delinquency that gradually supplemented older forms of incapacitation, servitude and hunger. ${ }^{25}$ The poor in Lagos were at that time mainly escaped slaves from the hinterland, girls sent to Lagos for cheap child labour, elderly beggars, the handicapped and friendless women. ${ }^{26}$ This poverty of age, sickness and slavery was still the chief form of poverty in late Victorian Lagos, but new forms of it were also appearing such as unemployment, which became a recurrent issue in the twentieth century. With closer integration into the colonial economy, Lagos became more vulnerable to international crisis. According to Susan Martin, Nigeria was hit by a long depression between I 9 I 4 and I $945 .{ }^{27}$ During this time, however, the expansion in the export volume of cocoa in the I 920 s ensured an unprecedented burst of prosperity for western Nigerian farmers. ${ }^{28}$

While there are no comprehensive statistics, fragmentary evidence suggests that unemployment was low during the I920s and high during the world wars and the I930s Great Depression. In I927, only I, ooo people were identified as unemployed by the Lagos Commissioner of Police. ${ }^{29}$ Effectively, there was a relative scarcity of labour in I 920 Lagos. ${ }^{30}$ But, by the late I920s this situation had dramatically changed. The cocoa price fall in 1928 combined with the growing concentration of ownership among European and Levantine firms had serious consequences for many African traders in the city. The Nigerian National Democratic Party (NNDP) asserted that 27,000 African traders had lost their jobs in Lagos by $1929 .{ }^{31}$

${ }^{22}$ Marris, Family and Social Change, I2-42; Baker, Urbanization, I II-I4; Sandra T. Barnes, Patrons and Power: Creating a Political Community in Metropolitan Lagos (London, I 986), 79-96. $\quad{ }^{23}$ Iliffe, The African Poor, I77.

${ }^{24}$ Marris, Family, 62. It should be noted that the author was writing shortly after Independence. $\quad{ }^{25}$ Iliffe, The African Poor, I64. ${ }^{26}$ Ibid. I64-7.

27 S. M. Martin, 'The long depression: West African export producers and the world economy, I9I4-45', in I. Brown, The Economies of Africa and Asia in the Inter-War Depression (London, I 989), 75-94. ${ }^{28}$ Ibid. 78.

${ }^{29}$ NAI, Comcol I, 69, Report by the Commissioner of Police of Lagos, 2 Sept. I927; NAI, Comcol I, 69, Letter of the Resident of the Colony to the Secretary of Southern Provinces, Lagos, 5 Sept. 1927.

${ }^{30}$ Ayodeji Olukoju, 'The travails of migrant and wage labour in the Lagos metropolitan area in the inter-war years', Labour History Review, 6 I ( I 996), 59.

${ }^{31}$ NAI, Comcol I, 894, Memorandum on trade depression, unemployment and income tax collection prepared by the NNDP, n.d. 
Simultaneously, the stoppage of public work caused great hardship for casual labourers. A total of 20,104 railway workers also lost their jobs. ${ }^{32}$ In April I935, the government set up an Unemployment Inquiry Commission which was particularly concerned with the high number of clerical workers registered as unemployed and the failure of school leavers to find work. ${ }^{33}$ In i 938 the Governor was informed that:

In Lagos and most other major towns law and order conditions have rapidly deteriorated. Government interest will have to be directed at the growing number of unemployed workers, at the large numbers of vagrant children who throng the market places and at political agitators who prey on the ignorance and misery of the unemployed. ${ }^{34}$

During the Second World War, owing to the shortage of supplies, many employers in the country had to dismiss most of their staff. To limit the influx of unemployed people into Lagos, a series of orders implemented in 1944 and 1945 closed worker registration to people from the provinces. ${ }^{35}$ Industrial and general economic growth in the r 950 os did not succeed in eradicating poverty in the city because of the rapid immigration rate. By I963, a United Nations team of experts considered that key problems in Lagos included the shortage of housing, the lack of housing finance, the large size of slum areas and the insanitary condition of most of the houses. ${ }^{36}$

While persistent poverty can be observed from the nineteenth century, it should be noted that the social geography of the twentieth-century city tended to exacerbate differences between rich residential areas and poor overcrowded wards. After Lagos was made the capital, it was decided that the city should combine a residential area reserved to Europeans and a commercial area in which Europeans lived, worked, traded and interacted with Africans. ${ }^{37}$ The two main islands of Lagos gradually became distinct. In Ikoyi, a European Reservation Area was laid out in 1928 to accommodate exclusively the increasing number of Europeans (30I in I90I to 4,000 in I93 I). Restrictions on residence continued till 1947 based on race and thereafter based on 'standard of living' ${ }^{38}$. On Lagos Island, the commercial core of the city, anyone was allowed to live and work (see Map I). Overcrowding and the lack of housing rapidly gave rise to a large slum. A few thousand inhabitants were resettled after the bubonic plague outbreaks in Yaba, a late I920s development on the mainland. ${ }^{39}$ In I95 I, the Central Lagos Slum Clearance Scheme scheduled the transfer of another 30,000 people to Suruele, six kilometres from the centre. Despite these schemes, Lagos Island remained

32 Olukoju, 'The travails', 59.

33 A. Hughes and R. Cohen, 'An emerging Nigerian working class: the Lagos experience, r 897-r 939', in P. C. W. Gutkind, R. Cohen and J. Copans (eds.), African Labour History (London, I 978), 49. 34 Ibid. 36.

35 Department of Labour, Annual Report, I945 and r946 quoted in Mabogunje, Urbanisation, $26 \mathrm{I}$.

36 Otto Koenigsberger et al., 'Metropolitan Lagos', Habitat International, 55 ( 1980), $55^{-8} 3$.

37 Ayodeji Olukoju, 'The segregation of Europeans and Africans in colonial Nigeria', in Fourchard and Albert (eds.), Security, 26 I-83.

38 Ibid. 282.

39 Olukoju, 'Population', 98-9. 
PLAN OF

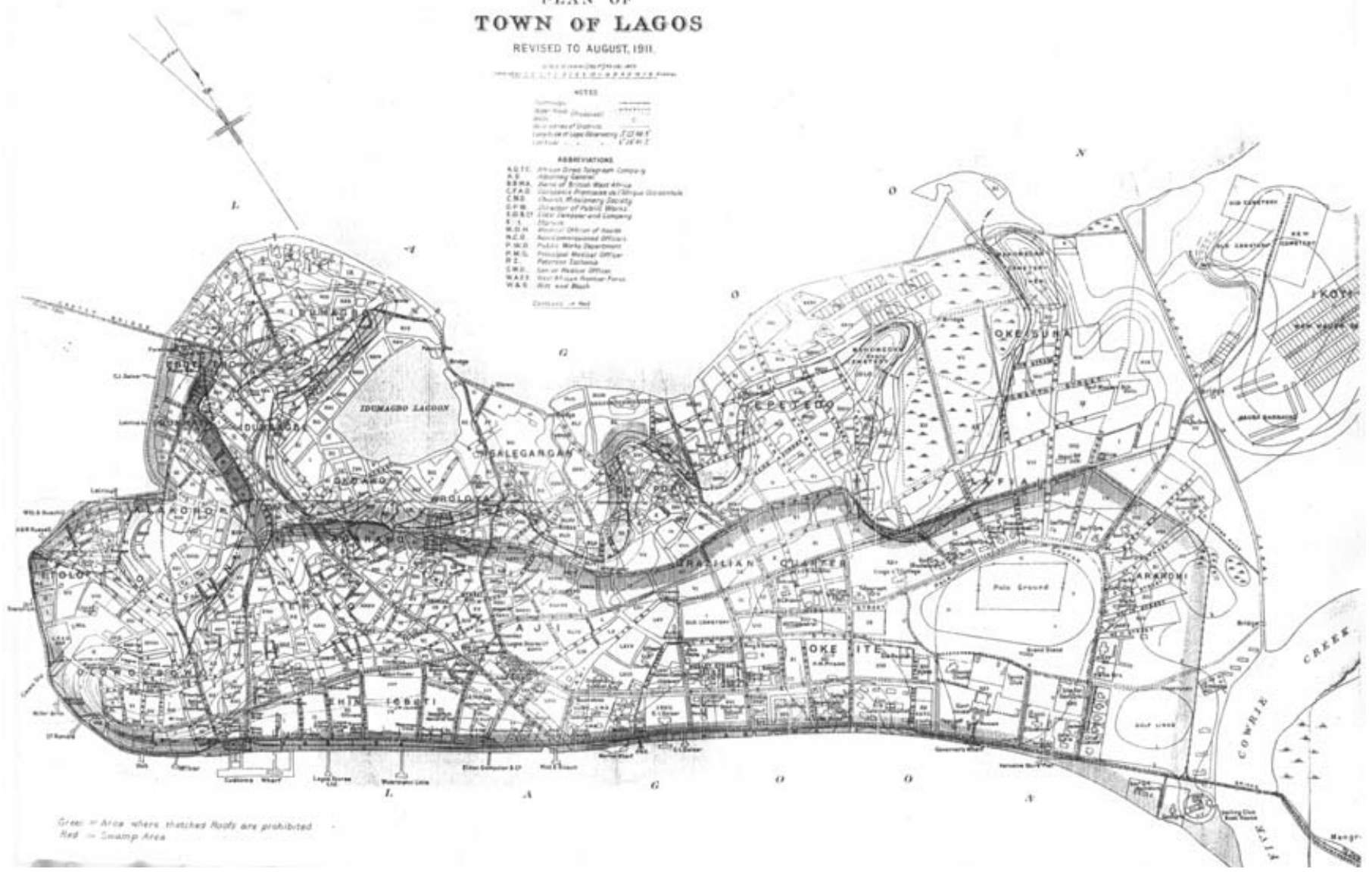

Map I. Lagos Island in i 9 I I. Source: Plan of Logos Island: CO г 047/65 I, Plan of town of Lagos, revised to August i 9i I. 
overcrowded, ${ }^{40}$ and had a unique mix of an educated elite, wealthy traders and a large poor African population. It was also for decades the main youth crime spot in the city. Other African migrants settled on the mainland along the railway at stations which gradually became small towns (Yaba, Surulere, Oshodi, Ikeja, Agege). Except for a few wards (Ebutte Metta, Yaba and Surulere) most of the mainland was largely unplanned. It was in the framework of rapid urban expansion and persistent poverty, henceforth dominated by unemployment and lack of housing, that youth crime took place.

\section{YOUTH AND CRIME IN COLONIAL LAGOS}

From a legal point of view, the young as a group were not defined until the I940s. In the various successive ordinances, there was, rather, a generic category called 'children' with fluctuating age limits: I7 in the Alien Children Ordinance of $\mathrm{I}_{878}$, I $_{5}$ in the Native Children (Custody and Reformation) Ordinance of $\mathrm{I} 928$, I 6 in the same I 928 Ordinance amended in I 932. ${ }^{41}$ The term 'young person' apparently first appeared with the Children and Young Person's Ordinance (CYPO), promulgated in Nigeria in I943, which clearly defined two categories: a child is under $\mathrm{I} 4$ and a young person is over I 4 and under $I_{7 .}{ }^{42}$ Later, the expression 'juvenile delinquency' included both children and young people. Thus, after I 945, juvenile delinquency statistics appearing in the Nigerian Police Annual Reports were divided into two groups: junior (under I 4 years of age) and senior (under I7 years of age). ${ }^{43}$ Because this paper deals with 'juvenile delinquency' it consequently refers to all the persons up to the age of seventeen.

Youth offenders were becoming more organized and more visible in Lagos from the mid-I920s. Before then there is no mention either in African newspapers like the Lagos Daily Times and the Nigerian Pioneer or in police reports of specific offences involving youths. The first indications appeared in official correspondence, police reports and Nigerian newspapers in the later I 920 s. ${ }^{44}$ From the I 920 s to the I 960 , three important features shaped the youth crime milieu: the increase in the number of young offenders, the affirmation of the existence of male offender youth groups and the emergence of an organized network of juvenile prostitution. These three points will be examined in turn.

A superficial reading of the scarce crime statistics would suggest an extraordinary increase in the number of youth offenders in Nigeria from the i 920 s to the ig6os, even given the growth of both the urban and the total population of the country (see Table 2). But statistics of juvenile offences are

40 25,000 peoples per square mile in I90 I, I25,000 people per square mile in I 963. Baker, Urbanization, 35 .

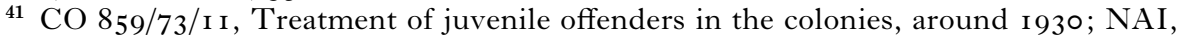
Comcol I, 2844, Faulkner, hawking by children in Lagos, Sept. I 942.

42 NAI, Comcol 2600, Patterson, Crime and its treatment in the Colony and Protectorate, Mar. I 944; CO 859/I 352, Advisory committee on the treatment of offenders in the colonies, draft memorandum on the care and treatment of children and young persons, I $96 \mathrm{I}$.

43 Annual Reports, the Nigeria Police Force, I 945-7.

44 However, while there is little evidence of juvenile offences in the early colonial period, further work still needs to be done. 
Table 2. Number of cases involving conviction of offenders under I7, I927-65

\begin{tabular}{lccc}
\hline \hline Years & I 927-30 & I 945-7 & I 963-5 \\
\hline True cases & $?$ & 3,049 & 6,009 \\
Convicted & I 20 & 2,537 & 3,690 \\
Cases awaiting trials & $?$ & 263 & I, 270 \\
Convicted per year & 30 & 845 & I , 230 \\
Offences relative to Nigerian pop. per I 00,000 & I.5 & 28. I & 22.3 \\
Offences relative to urban pop. per I 00,000 & 2 I & 264 & I I 6 \\
\hline \hline
\end{tabular}

Sources: Annual Reports, Nigeria Police Force, I945-7, Tekena Tamuno, The Police in Modern Nigeria, I86I-1965: Origins, Development and Role (Ibadan, I970), 300; CPO, I68 I, I Director of Prisons Southern Provinces to Secretary Southern Provinces, 9 Jan. I 93 I.

like other criminal statistics: they represent both the activities of the judicial system and the activities of the offenders.

The difference in the level of convictions between the late ig2os and I $945^{-7}$ is to be explained both by the increase in the number of offenders and by the implementation of a new judicial procedure to deal with youth offenders in 1945 (see below). The Senior Resident in Lagos considered that the average number of cases involving juveniles convicted in Nigeria was only 30 a year between 1927 and I 930 , but rose to I I 2 cases in 1934 and ${ }_{5} 8$ cases in $1935 .{ }^{45}$ The very high proportion of petty offences against property was a structural feature of youth offences during the colonial period as a whole: thefts of less than five pounds comprised half of the cases brought before the Juvenile Court of Lagos in $1945^{-7}$ and in the r 960 s. $^{46}$

The second feature of the period is the emergence of youth criminal groups. There is only limited evidence of offences committed by youth gangs in early colonial Lagos, but this period needs further research. Cases reported by the Nigerian Pioneer in I923 and I924 involve single young pickpockets operating in crowded places (the post office, railway stations and Tinubu square). ${ }^{47}$ Later in the I 920s, criminal activities reported both in Lagos and Ibadan are more often by youth groups known as Faguda Boys. ${ }^{48}$ The term Faguda means pickpocket in Yoruba. The first recorded instance concerns a well-known Lagos pickpocket called Salami Jaguda who was sentenced to nine months' hard labour for stealing a huge sum of money from a rich merchant in $1924 .{ }^{49}$ The term, however, does not designate an organized group of youth offenders before the end of the r92os in Lagos and the beginning of the r 930 s in Ibadan. The way that Lagos newspapers

45 'The police magistrates', Nigerian Daily Times, 3 I July 1936.

${ }^{46}$ Police Annual Report, I 945-7; Alan Milner, The Nigerian Penal System (London, I972), 352.

${ }^{47}$ 'Pickpockets at the general post office, Lagos', Nigerian Pioneer, 3 Nov. I923; 'Pickpockets again at the central post office', Nigerian Pioneer, 7 Dec. 1923; 'Pickpocket in Iddo railway station', Nigerian Pioneer, 7 Nov. I 924; 'Pickpocket in Lagos', Nigerian Pioneer, 4 Dec. I924. ${ }^{48}$ Heap, 'Jaguda Boys', 324; Fourchard, 'Urban poverty', 298.

49 'Pickpocket in Lagos', Nigerian Pioneer, 4 Dec. 1924. 
reported these cases actually shows the discovery of an apparently new phenomenon. In 1 926, the attention of the Nigerian Pioneer 'has been called to the frequency of assaults on girls by young men and boys ... the molestations which follow usually elicit retorts and a squabble follows [sic]'. ${ }^{50}$ The Lagos Daily Times mentioned 'certain bands of young men who parade certain portions of the town armed with sticks or whips. This particular type of hooliganism shows no sign of decreasing and is particularly prevalent during Christmas week'. ${ }^{51}$ In I 929, several reports reached the Lagos Daily Times about repeated attacks on Carter Bridge between Iddo Station (the terminal station of the Kano-Lagos railway) and Lagos Island:

These pickpockets ... would follow (the strangers) to the middle of the bridge, and pretend to be fighting one with the other and eventually knock or push themselves against the strangers who would be confused, and in such confusion they rob the poor fellows of whatever cash they may be having on them. ${ }^{52}$

Faguda Boys were originally practical associations of destitute street boys who operated in small groups in order to frighten their victims. ${ }^{53}$ They are the historical parents of the present Area Boys with whom they share some common practices. ${ }^{54}$ They provoked quarrels in the streets to relieve the victims of their money during the confusion before escaping. They developed collective strategies with shared responsibilities to minimize the risk of being arrested by the police. They generally extorted money from easy targets (strangers, farmers, women) and their main places of activities were streets, markets and crowded public places such as motor parks, train and bus stations.

During the Second World War, the expression Boma Boys appeared in the Lagos press. The term was probably brought to the West Coast of Africa from America where a 'bum' was a vagrant, a good-for-nothing. ${ }^{55}$ The term referred to young boys who acted as unlicensed guides for the thousands of African and European soldiers who stopped in Lagos during the war. Originally, Boma Boys guided them from the port to various places in Lagos such as canteens, bars, night clubs and brothels. ${ }^{56}$ Because Boma Boys shared the same public space and often the same practices as the Faguda Boys they were often considered as an identical menace during that period. A more comprehensive enquiry into these groups was conducted by Donald Faulkner, the first Welfare Officer of the colony, in I 94I. According to him, there were two groups of boys: "The under twelve group was composed of children left stranded in Lagos, orphans, runaways from home and boys brought to Lagos by older people. They live by begging, petty theft and are in poor physical conditions'. ${ }^{57}$ The over-I 2 group fell into three

50 'Assault on a girl', Nigerian Pioneer, 29 Jan. 1926.

51 'Local hooliganism', Lagos Daily News, 2 I June 1929.

52 'Pickpocketing pestilence: violent practice on Carter bridge', Lagos Daily Times, 2 May 1929.

${ }^{53}$ Fourchard, 'Urban poverty', 298.

${ }^{54}$ Abubakar Momoh, 'The political dimension of urban youth crisis: the case of the

Area Boys in Lagos', in Fourchard and Albert (eds.), Security, i 86-7.

55 'Boma Boys', West African Pilot, i6 Nov. i 940.

${ }^{56}$ NAI, Comcol I, 2600, A Report on social welfare on the Colony and Protectorate by Alexander Patterson, Mar. I 944.

${ }^{57}$ NAI, Comcol I, 247 I, Juvenile delinquency in Lagos by Donald Faulkner, I 94I. 
sub-groups: inexperienced and destitute boys, delinquent adolescents and Boma Boys. The difference among the three groups is probably the level or organization. Boma Boys are considered here to act as a collective group which could be involved in serious crime:

At the first stage, he is a simple unsophisticated out-of-work, introduced to the trade by a friend, a casual guide without an arrangement with a particular house. He has not the experience to make the work very remunerative, so he still sleeps outside and leads rather a meagre existence. When he becomes more experienced and by his glib tongue and polite manner, can get more customers, he lives in a house, dresses well and feeds well. He may earn upwards of $f 2$ per month. He probably has a definite arrangement with special harlots or a particular house. He is gradually deteriorating morally and eventually becomes a sophisticated cynical youth, up to all the tricks of the trade, lazy and immoral, perhaps acting as a master to a group of younger Boma boys. He may now be working on a percentage basis as an important partner of an organised trade. ${ }^{58}$

In the I950s, the terms 'thugs' and 'touts' seem to have partly replaced the former Faguda and Boma Boys in the press. ${ }^{59}$ Unemployed youth, motor park touts and youth criminals were also further used as bodyguards and bullies by political parties to intimidate opponents in the r95os and the r 960 , especially in south-western Nigerian cities. ${ }^{60}$

The third and last feature of the period is the development of a network of juvenile prostitution that became a subject of concern when it was discovered by Faulkner during the war. He found that young prostitutes around the age of 12 were coming mainly from Owerri and Calabar Provinces (Ibos, Efiks, Sobos, Urhobos). ${ }^{61}$ We know little about the first province except that some girls had been kidnapped, pawned or sold to patrons under the guise of marriage, or disposed of at Oguta Abaziem in Owerri in the 1920s. ${ }^{62}$ It is highly probable that such practices continued in the ro3os and the ig40s. According to social workers, a dowry was paid to the parents of young girls who were sent to Lagos, for permission not to marry them but to introduce them to the life of prostitution. ${ }^{63}$ Prostitution networks from Calabar Province were developing from the I920s with the migration of women from the Upper Cross River Basin. ${ }^{64}$ By the I920s, prostitution had become a substantially developed trade in the region and most of the prostitutes migrated to other parts of Nigeria and to West African ports, mainly Calabar, Lagos, Port Harcourt, Accra and Sekondi-Takoradi in the Gold Coast. ${ }^{65}$ Juvenile prostitutes coming from the same areas were soon

58 Ibid.

59 The term Faguda and Boma Boys disappeared from newspapers both in Ibadan and Lagos.

60 Heap, 'Jaguda Boys', 34I ; Kemi Rotimi, The Police in a Federal State: The Nigerian Experience (Ibadan, 200I), I40; Remi Anifowose, Violence and Politics in Nigeria: The Tiv and Yoruba Experience (Enugu, I982), 230-4.

61 NAI, Comcol I, 2844, Child Welfare, Prostitution and Child Marriage, n.d.

62 F. Ekechi, 'Pawnship in Igbo society', in P. Lovejoy and T. Falola (eds.), Pawnship, Slavery and Colonialism in Africa (Trenton, 2003), I 79.

63 NAI, Comcol I, 2844, Child Welfare.

64 Benedict B. Naanen, 'Itinerant gold mines: prostitution in the Cross River basin of Nigeria, I930-I950’, African Studies Review, 34 ( I991), 59.

65 Ibid. 60. 
involved in that trade and by $\mathbf{9} 940$ the juvenile prostitution of Efik girls was considered to be as much of a nuisance in Lagos as it was in Calabar. ${ }^{6}$ The number of soldiers stationed in Lagos during the war increased and diversified forms of prostitution as it did in many other African cities like Addis Ababa and Nairobi where troops were stationed. ${ }^{67}$ In r 946, the Seven Seas Hotel, the Traveller's Inn and the Crystal Garden Club were known in Lagos Island as brothels patronized by Europeans and managed by elderly women in charge of several young girls between $\mathrm{I} 2$ and $\mathrm{I} 5$ years old. ${ }^{68}$ Boma Boys looked out for drunken seamen whom they conveyed to these places. Taxis opposite the Tinubu Police Station offered to take Europeans to girls, either in brothels or in private rooms, and, if the client especially asked for young girls, the prostitute provided a young relative and kept the money for herself. ${ }^{69}$

THE EMERGENCE OF THE 'JUVENILE DELINQUENCY PROBLEM'

The colonial state had begun to take care of children and youth offenders before the Second World War. Colonial governments opened reformatories for children in the r880s in South Africa, in I888 in Senegal, in I904 in Guinea, in 1909 in Kenya. ${ }^{70}$ However, the low numbers involved showed how few juvenile offenders appeared before the courts and reflected how little concern for such questions was expressed by colonial administrations. ${ }^{71}$ As Florence Bernault notes, 'political and penal inertia, plus the deficiency of material and intellectual resources among colonizers, prevented colonial regimes from implementing any project of grand renfermement in Africa, with arguably, the exception of South Africa'. ${ }^{72}$ South Africa soon raised the issue of juvenile offenders. From the r 93 os onwards, the African elite, welfarists, the Johannesburg Non-European Affairs Department and the central government all saw 'juvenile delinquency' as a social and moral crisis that had to be headed off. ${ }^{73}$ But public debate on this issue was probably more the exception than the rule in African colonies. ${ }^{74}$ Nigeria was typical: there were no government social welfare organizations and social problems were either ignored or, to a very limited extent, dealt with by the Christian missions and

66 NAI, Comcol I, 2844, Calabar Council Office, Child prostitution in Lagos, I 7 Jan. I 943 .

${ }^{67}$ Luise White, The Comforts of Home: Prostitution in Colonial Nairobi (Chicago, I 990), I 47-84; Denise Laketch, The Commoditization of Female Sexuality: Prostitution and Socio-Economic Relations in Addis Ababa, Ethiopia (New York, I991), 2 I-42.

68 NAI, Comcol I, 2844, A. Izzett, Child Prostitution in Lagos, I 5 May I 946.

69 Ibid.

70 F. Bernault, 'De l'Afrique ouverte à l'Afrique fermée: comprendre l'histoire des réclusions continentales', in Bernault (ed.), Enfermement, 33; D. Killingray, 'Punishment to fit the crime? Penal policy and practice in British colonial Africa', in Bernault (ed.), Enfermement, 202.

71 Between $\mathrm{I} 5$ and 20 inmates in the pénitencer agricole of Bombey (Senegal) or Kindia (Guinea) in the I 920 s. Thioub, 'Marginalité', 2 I 6-i 7.

${ }^{72}$ Florence Bernault (ed.), A History of Prison and Confinement in Africa (Portsmouth NH 2003), 26.

${ }^{73}$ Glaser, Bo-Tsotsi, $2 \mathrm{I}$.

74 In Dar es Salaam, the 'problem of urban youth' became a serious concern by the late I 930s. Burton, 'Urchins', 200. In French West Africa, it was not considered an important issue before the r 95 os. 
a very few voluntary organizations. Major problems of destitution were dealt with by the people themselves through 'family and tribal customs' ${ }^{75}$

At the beginning of the r93os, the Colonial Office set up a committee to consider what special arrangements were in force in the Empire for the trial and punishment of young offenders. ${ }^{76} \mathrm{~A}$ draft bill proposed by an advisory committee recommended the introduction in the various colonies of provisions, such as special detention facilities, probation officers and juvenile courts, to separate juveniles from adults and prevent them from becoming hardened criminals. ${ }^{77}$ Since the 1850 , British courts had been allowed to sentence any child convicted of an offence to a reformatory for between two and five years and to send children found begging or 'without means of subsistence' to an industrial school for an indefinite period. ${ }^{78}$ Probation officers and juveniles courts were introduced later through the Probation of Young Offenders Act of 1907 and the Children's Act of I 908 because reformers considered that juveniles were less responsible than adults for their actions and should not be subjected to the full weight of the law. ${ }^{79} \mathrm{~A}$ specially selected panel of magistrates to hear juvenile cases was appointed and magistrates were asked to take primary account of the 'welfare of the child'.

Top officials in the administrative system in Nigeria reacted vigorously against the introduction of such measures in the colony. Three main arguments were advanced. First, the measures would be useless because of the very limited number of young offenders in the colony. ${ }^{80}$ Second, some guarantees were already given to young offenders through existing legislation that had established specific institutions for children (Native Children Ordinance of I928) and segregation in prisons for juveniles under I4 years (Prison Ordinance of I 9I 7). ${ }^{81}$ Third, the Governor-General of Nigeria, Sir Donald Cameron (I93 I-5), considered that the provision of reformatories and the appointment of probation officers would require considerable expenditure. ${ }^{82}$

In fact, legislation against young offenders in Nigeria was inadequate in the I930s. The Native Children Ordinance applied mainly to children who were orphans, deserted by their relatives or who had been sold as slaves, and not to children or young persons who had committed offences. ${ }^{83}$ There was only one alternative for juvenile offenders: either they were sent to prison without being segregated from adults because there was no other provision, or they were given corporal punishment. As a comprehensive

${ }^{75}$ NAK, Ministry of Social Welfare and Community (MSWC), I226, Report by Mr Chinn, social welfare adviser to the Secretary of State, Feb. I950.

${ }^{76} \mathrm{CO} 859 / 73 / 1_{3}$, Juvenile delinquency sub-committee, Draft report, n.d. (around I942).

${ }_{77}$ CPO, I68I, I, Governor-General to the Secretary of State, 26 Feb. I93 I.

${ }^{78}$ Respectively, I 854 Youthful Offenders and I857 Industrial Schools Acts; John Muncie, Youth and Crime: A Critical Introduction (London, I999), 6r.

${ }^{79}$ Ibid. 66.

${ }^{80}$ CPO, I68I, I, Senior Resident to the Secretary Southern Provinces, I 5 Apr. I93 I.

${ }^{81}$ CPO, I68 I, I, Secretary Southern Provinces to Chief Secretary to the government, I 9 Jan. I 932.

${ }^{82}$ CPO, I68I, I, Governor-General to the Secretary of State, 3 July i 93 I.

${ }^{83}$ CPO, I68I, I Director of Prisons Southern Provinces to Secretary Southern Provinces, 9 Jan. I93I. 
report on Nigerian prisons in 1944 stated, 'a certain number (of youth) are admonished and sent away, a very large number are beaten and returned to the very environment that caused their offence, a very few are indeed sent to a training school' ${ }^{84}$

By 1930 , the only institution dealing with young offenders in Southern Nigeria was run by the Salvation Army, a private body that was making a considerable effort to enter tropical Africa between the wars. ${ }^{85}$ The Industrial Army Home in Yaba (a few miles from Lagos Island) was a reformatory built in 1926 to accommodate forty boys convicted in the colony of Lagos. ${ }^{86}$ The school was considered inefficient in a 1944 report, however. 'Yaba school has no clear purpose or method, its staff is inadequate and unsuitable, its expense inexplicable' ${ }^{87}$

Moved by the need to take into consideration some of the recommendations of the Colonial Office, the government consented to establish a new 'approved school', in Enugu, headquarters of the Eastern Provinces, in I 933. ${ }^{88}$ Administered and financed by the Prisons Department, the establishment was not very different from what was then in existence in some other colonial territories: industrial training (carpentry, blacksmithing, tailoring, shoemaking and gardening) was provided by five teachers while more formal schooling tried to give the pupils an elementary level of English. ${ }^{89}$ Donald Faulkner, a Home Prison Service official specializing in social welfare in the United Kingdom was appointed as the first professional director of the school (I937-4I). ${ }^{90}$ By r 940, the Lagos and Enugu schools were only housing around 100 boys (40 in Lagos, 64 in Enugu) from the colony and the Southern region. Nobody within the colonial administration in Nigeria considered juvenile offending as a problem in the r 930 . Indeed, it was largely ignored and the existing ordinances were considered to be comprehensive enough to deal with the few cases.

If the issue of youth offenders was largely ignored by the local administration it was covered by African newspapers in Lagos which soon protested against criminal activities as well as youth offenders. The Nigerian Pioneer (founded in I914) and the Nigerian Daily Times (1926) were undoubtedly more conservative and less critical of the administration than the Lagos Daily News inaugurated in 1925 by Herbert Macaulay and the West African Pilot funded in 1937 by Nnamdi Azikiwe. ${ }^{91}$ However on the issue of youth criminal activities, all these newspapers represented the voice of an educated elite of journalists, lawyers and civil servants against a group invariably described as 'ruffians', 'young scoundrels', 'undesirable pests', 'hooligans' and more generally considered as a 'menace' to the

${ }^{84}$ NAI, Comcol 2600, Patterson, Crime and its treatment in the Colony and Protectorate, Mar. I $944 . \quad{ }^{85}$ Iliffe, The African Poor, i 96.

${ }^{86}$ CPO, I68I, I Director of Prisons, I93 I, Senior Resident, I93 I.

87 NAI, Comcol 2600, Patterson, Crime, I 944.

${ }^{88}$ In 1932, industrial schools and reformatories were amalgamated as Approved Schools in Britain.

${ }^{89}$ NAE, Civil Secretary's Office (CSO), I 395, Report on Industrial School of Enugu, 29 Oct. I 938; Report on Industrial School of Enugu, 6 Apr. 1939.

90 NAE, CSO, I 449, I, Victor Mabb, Director of Prisons to the Chief Secretary to the government, Lagos, 2 I July I 94I.

${ }^{91}$ James S. Coleman, Background to Nationalism (Berkeley, I985), I 85, I92, 22 I. 
society. ${ }^{92}$ Yet the issue did not catch the attention of the major nationalist leaders in Lagos who were involved in increasing political competition from the I 920 s onwards. ${ }^{93}$ They did not write any of the articles concerned, which did not generally appear on the front page. However, many victims did report their experiences to Lagos newspapers which then affirmed them as representing the voice of 'peaceful tax payers and law abiding citizens'. ${ }^{\mathbf{4}}$ Most of the newspapers - even the more conservative ones - were critical of government handling of crime. They recommended increasing the number of policemen in specific hot spots and denounced the lack of police presence on the mainland to protect an emerging African working class against armed robbers. ${ }^{95}$ However, welfare policies implemented during and after the Second World War provoked more adverse reactions from different political parties, especially when it concerned juvenile prostitution and hawking by young girls (see below).

During the I930s, repeated complaints against Faguda apparently did not modify the administration's perception of youth. Its position probably changed when the Governor-General declared, in November I 940, that the 'activities of the Boma Boys were becoming something very much worse than a mere nuisance'. ${ }^{96}$ This was followed in December by the promulgation of the Unlicensed Guides (Prohibition) Ordinance that punished severely the harassment of European and African soldiers by Boma Boys. This local ordinance should be seen as a reaction against a group that was considered unpatriotic in wartime. Within two months, seven articles on Boma Boys had appeared in the Nigerian Daily Times and the West African Pilot congratulating the government's initiative. If the ordinance had little effect, ${ }^{97}$ it did show, for the first time, that the colonial administration and the educated elite shared a common determination to fight young offenders.

This interest was not totally new in the Colonial Office. A colonial Penal Administration Committee was appointed in 1937 to advise the Secretary of State on penal matters in general and on 'various problems affecting juvenile delinquents' in particular. ${ }^{98}$ By the end of the r 930 s, riots in the West Indies, where destitution was widespread, had given rise to a new strategy of development and welfare for the whole colonial empire. ${ }^{99}$ It was, however, the local situation in Lagos that forced the Colonial Office to readdress the issue of juvenile delinquency. Just after the promulgation of the Unlicensed Guide

92 'Assault on a Girl', Nigerian Pioneer, 29 Jan. 1926; 'Pickpocketing pestilence', Lagos Daily Times, 2 May 1929; 'Boma Boys', West African Pilot, i6 Nov. I940; 'This Jaguda menace', West African Pilot, 22 Nov. I940; 'The Boma boy menace', Nigerian Daily Times, 30 Dec. I 940; 'Menace of pickpockets', Nigerian Daily Times, 27 Oct. I 94I ; 'Pickpockets at large', Nigerian Daily Times, ıо Apr. I942; 'The Jaguda menace', Nigerian Daily Times, 2 Apr. I942; 'A case for action', Nigerian Daily Times, I 2 June I 943 .

${ }_{93}^{93}$ Fred I. A. Omu, Press and Politics in Nigeria, I880-I937 (Ibadan, I 978), 227-40.

94 'Hooliganism in Lagos streets', Nigerian Daily Times, i 8 May 1946.

${ }_{95}$ Fourchard, 'Urban poverty', 3 I 0.

96 'Boma Boys', West African Pilot, i 6 Nov. 1940.

${ }^{97}$ Faulkner observed in 1943 that 'sailors are being pestered by Boma Boys all around the town'. NAI, Comcol I, 2600, Colony Welfare Officer, Children welfare, general question, i 8 May i 943.

${ }^{98} \mathrm{CO}, 859 / 73 / 13$, Juvenile delinquency sub-committee, draft report, n.d. (around I942).

99 Iliffe, The African Poor, 200. 
Ordinance, the Governor of Nigeria asked Donald Faulkner, then Director of the Approved School at Enugu, to investigate vagrant boys in Lagos. After submitting Faulkner's report, the Governor-General asked the Colonial Office to appoint an officer responsible for juvenile welfare in Lagos. ${ }^{100}$ This request, combined with the willingness of the Governor of Sierra Leone to build a reformatory school in Freetown, led the Colonial Penal Administration Committee to set up a Juvenile Delinquency sub-committee with the task of considering 'the question of juvenile delinquency in the Colonies and the Dependencies with a view to its prevention and proper treatment'. ${ }^{101}$ Alexander Patterson, Commissioner of Prisons for England and Wales and chairman of the committee, decided to appoint Donald Faulkner as the first Social Welfare Officer in the British Empire. ${ }^{102}$ The Juvenile Delinquency sub-committee, renamed the Child and Youth Welfare sub-committee after the War, was composed of top colonial advisers and welfare officers and had the task of advising the Colonial Office on the best way to deal with youth and children in the colonies. It was largely influenced by the way British children and youth had been dealt with by reformers.

From I 94I to I943, Faulkner produced various reports based on his Lagos fieldwork. ${ }^{103} \mathrm{He}$ initially considered poverty, the breakdown of the 'traditional African family' and urbanization as the main causes of the rise of juvenile destitution and youth offences, but the sociological data tended to show that lack of parental control was central. Among the 229 boys who passed through the Green Triangle Hostel between February I942 and August I 943, only 78 had parents living in Lagos. Faulkner came to the conclusion that 'the lack of a permanent and stable home is the main factor'. ${ }^{104}$

Most of the activities identified as dangerous for children and youth took place in the street: working, hawking, trading, prostitution. Consequently, most of Faulkner's recommendations were oriented towards one main objective: to remove children and youth from the criminal influence of the street. Prevention and repression constituted the two sides of his recommendation. In order to keep boys and girls off the street, Faulkner advocated the development of youth clubs and playing facilities (playing fields for football, swimming pools and so on). At the same time, hostels could be used to keep children from delinquency as paupers, street traders, beggars and school boy drop-outs, to assist those in need of 'care and protection' (handicapped, orphans, juvenile prostitutes) and to provide a safe haven separated from adults for children awaiting trial or repatriation. ${ }^{105} \mathrm{He}$ also proposed to ban female child hawking because girls 'were criminally assaulted and seduced at a very tender age', i.e. 'at I 3 years of age or under' ${ }^{106}$

$100 \mathrm{CO}, 859 / 73 / \mathrm{I}_{3}$, Colonial Penal Administration Committee, minutes of the 19 th meeting of i2 Feb. I 942. ${ }^{101} \mathrm{CO} 859 / 73 /$ I 3, Juvenile delinquency sub-committee.

102 NAI, Comcol 2600, Patterson, Crime, I 944.

103 NAI, Comcol I, 247 I, Juvenile delinquency, I 94I ; NAI, Comcol I, 2844, Hawking by children in Lagos by Donald Faulkner, Sept. I942; NAI, Comcol I, 2600, Donald Faulkner, Report on the scheme for dealing with juvenile delinquency in Lagos from Feb. I 942 to Aug. I943, 23 Aug. 1943, Donald Faulkner, Report on Juvenile Welfare in the Colonies, I 5 July i 943.

104 NAI, Comcol I, 2600, Faulkner, Report on the scheme, I943. $\quad{ }^{105}$ Ibid.

106 NAI, Comcol I, 2844, Faulkner to the President of Lagos Town Council, Hawking by children in Lagos, Sept. I 942. 
Most of these responses could be seen as a transfer of British reform philosophy and practices to the colonies. Since the nineteenth century, city streets had been perceived as potentially criminal spaces and criminal youth behaviour had become firmly associated with working-class family life. The proper place for women was the home rather than the street. Boys and girls' clubs had a similar objective of providing discipline, regulation, guidance and improvement. ${ }^{107}$ The colonial state wanted to intervene in African family life just as the British state had done in working-class family life in order to ensure that children were 'properly' educated, disciplined and given moral guidance. Yet, if the philosophy was quite similar, policy was different, and lack of finance denied the colonial state the power to control African urban life.

THE 'TREATMENT OF JUVENILE DELINQUENCY'

The first problem was the law. The Childrens' Ordinance and market regulations made no provision for the prosecution of youths between I 4 and 18 or for controlling juvenile activities. In I 942, a resolution banning street trading for girls under I 4 was passed in the City Council of Lagos, ${ }^{\mathbf{1 0 8}}$ but, without social service staff, it was not enforced. In I943, Faulkner convinced the government to promulgate the CYPO, a colonial adaptation of the 1933 Children and Young Persons Act in Britain. Again, without a welfare service, it was impossible to implement. Consequently, the creation of a specific welfare department was strongly advocated by Patterson, who visited Nigerian prisons in I 944: 'Social welfare in Lagos will take the field against poverty, overcrowding and cruelty. It will help to operate the new Ordinance dealing with Juvenile and Young persons. It will plead for the abolition of child hawkers' ${ }^{109}$ He concluded that the new social welfare service in Lagos was the appropriate means of preventing juvenile delinquency in Nigeria. Most of the Faulkner and Patterson recommendations were implemented just after the war.

Welfare services set up during or after the Second World War in British colonies strongly focused on juvenile delinquency probably because of the remit originally given to the Colonial Office Child and Youth Welfare sub-committee. This initial focus gradually changed in the r95os when welfare services implemented community development policies in many colonies. ${ }^{110}$ In Nigeria, however, juvenile delinquency remained the main task of the welfare service till the end of the colonial period. Here a whole set of social workers, probation and police officers had clearly identified a recurrent 'youth crime problem' and implemented new policies that dramatically changed the perception of youth. By i 945, a Juvenile Court was set up, soon to be followed by a Juvenile Court Police Force consisting of one Inspector and twelve other ranks in charge of escorting, enquiries, court work and repatriation to the country. ${ }^{111}$ Mr Chinn, Chairman of the

107 Muncie, Youth, 6o, 74.

108 'Free education and street hawking in Lagos debates', Nigerian Daily Times, 25 Sept. I 942.

109 NAI, Comcol I, 2600, A report on social welfare on the Colony and Protectorate by Alexander Patterson, Mar. I944. $\quad 110$ Iliffe, The African Poor, 202-4, 207.

111 NAI, Comcol I, 2796, Commissioner of the Colony to the Superintendent of Police, 3 July 1946. 
sub-committee within the Colonial Office, considered this juvenile police force as unique in the British Empire. ${ }^{112}$ The welfare service mainly concentrated on Lagos: in 1950, 8 European officers and 33 African assistants worked in the capital whereas only 3 European officers operated in the three other regions together. ${ }^{113}$ Lagos's welfare service now had the means to implement the CYPO.

One of the central issues for an effective implementation of the ordinance was the protection of young girls. The appointment of the first female Welfare Officer, Alison Izzett, in 1946, was another key step in the implementation of the law. After a three-month observation of girls passing through the girls' hostel, she offered new evidence of the criminal effects of street trading. Young prostitutes of I 4 and I 5 years old were working in brothels. Girls brought to Lagos with the promise of marriage were generally being used as prostitutes, and among the 35 girls between 7 and 16 years old admitted to the hostel, only 12 were still virgins. ${ }^{114}$ Her report convinced the Commissioner of the Colony to suppress child hawking. ${ }^{115}$ Section 25 of the CYPO became the central clause and reinforced the resolution proposed by Faulkner in $\mathbf{I} 942$ for raising the limit age for female street trading to 16 years:

No boys or girls under the age of 14 (can) sell or hawk ... in the streets. This applies also to any girl between the ages of 14 and $\mathrm{I} 6$, unless she is employed by her father or her mother or by the guardian appointed by a court. These laws do not apply to any boy over the age 14 or to any girl over the age of i 6 . Even if employed by her parents no girl under I 6 may hawk or sell after $6.30 \mathrm{pm}$ at night or before 6 am. ${ }^{116}$

The welfare service failed to appreciate the historical roots of juvenile street hawking in Lagos. The sexual division of labour was a long-established tradition in Yoruba cities: men were mainly farmers and craftsmen while women were engaged in food processing and trading. Many of these activities, especially hawking cooked food, took place outside the marketplace, and female children as young as six years old were sent around the neighbourhood for a small profit generally given to their parents. ${ }^{117}$ The law also forbade girls under i 6 to come alone to Lagos unaccompanied in order to limit the employment of juvenile girls by 'immoral' guardians. However, being accommodated by a family member was often the only way for young girls from the country to attend secondary school in Lagos or to work and collect savings before returning home to look for a husband. ${ }^{118}$ While it is

112 NAK, MSCW, I 226, Report by Mr Chinn, Social Welfare Adviser to the Secretary of State, Feb. I 950. 113 Ibid.

114 NAI, Comcol I, 2844, Izzett, Child Prostitution, I 946.

115 NAI, Comcol I, 2844, Acting Commissioner of the Colony to the Chief Secretary to the government, 2 I May I 946.

116 NAI, Comcol I, 2844, Regulations to prevent children trading in the street, n.d.

117 Nathaniel A. Fadipe, The Sociology of the Yoruba (Ibadan, I 970), I 49-55; T. Falola, 'Gender, business and space control: Yoruba market women and power', in B. H. Midamba and F. K. Ekechi (eds. ), African Market Women and Economic Power: The Role of Women in African Economic Development (London, I 995), 26-7; B. A. Lawal, 'Markets and street trading in Lagos', in S. Salm and T. Falola (eds.), Nigerian Cities (Trenton, 2003), 243 .

118 Marris, Family, 62-3. 
obvious that some children were sexually abused, the ordinance considered the entire system of hosting girls by guardians as a key feature of child prostitution. Rather than fighting prostitution networks, which was more the task of the police than the welfare service, the ordinance gave the means to control girls' movements.

The welfare service found some support from women in the educated elite, especially the Lagos Women's League funded in 1923 by Charlotte Olajumoke Obasa, who wanted to improve education and employment for women in Lagos. ${ }^{119}$ Mrs. Obasa was regarded as a member of the 'collaborating elite' who enjoyed social acceptance in the white community. ${ }^{120}$ After a meeting with Faulkner in 1942, the League formed a Women's Welfare Council which lobbied the Lagos Town Council to prohibit the employment of girls under I 4 as hawkers. ${ }^{121}$ The service also benefited from the support of tribal unions since prostitution was supposedly spoiling the reputation of their cultural traditions in Lagos. As early as I 943, 'local unions representing tribes involved in prostitution in Lagos' pressed the Welfare Officer to stop the business. ${ }^{122}$ The Urhobo Union agreed to find accommodation for Urhobo girls recruited into prostitution, ${ }^{123}$ and the Calabar Native Authority agreed with the welfare officer's suggestion that black lists of 'procurists' (sic) and prostitutes be compiled and published. ${ }^{124}$ Within this framework, these unions were ready to restrict their girls' freedom.

The ordinance in force from June 1946 enabled the government to bring in more girls suspected of being in 'moral danger' and to make the registration of girls entering or leaving Lagos compulsory. The Criminal Investigation Department was asked to assist the Welfare Office in arresting girls, and to pursue the organizers of child hawkers and touts while tribal union members kept trains arriving from the country under surveillance. ${ }^{\mathbf{1 2 5}}$

Lagos market women, however, soon opposed the ordinance. A delegation of the Women's Party, an exclusively women's organization funded in 1944 by Mrs Oyinkan Abayomi, officially protested against the detention of girls by the welfare service and especially the medical examination of a girl's virginity. ${ }^{126}$ Throughout the I940s, the NNDP, which had supported the interests of market women since the r 920 , organized a number of meetings to protest against the arrests of child hawkers. ${ }^{127}$ Most of the newspapers inveighed against abuse of freedom, indiscriminate arrests, violation of private life, heavy penalties (offenders were fined $f_{5}$ ) and pointed out that innocent hawkers were obliged to stay in a hostel with real delinquents and

119 G. O. Olusanya, 'Charlotte Olajumoke Obasa', in B. Awe, Nigerian Women: A Historical Perspective (Ibadan, I 992), I 23-39.

${ }^{120}$ Nina Emma Mba, Nigerian Women Mobilized: Women's Political Activity in Southern Nigeria, I900-I965 (Berkeley, I982), 2 I 4.

121 Ibid. 2 I 8

122 NAI, Comcol I, 2844, Faulkner, Child Prostitution, I 943.

${ }^{123}$ NAI, Comcol I, 2844, Memorandum from the Colony Welfare Officer, 7 Aug. I 943.

124 NAI, Comcol I, 2844, Calabar Council Office to District Officer Calabar, I 7 Jan. I 944 .

${ }^{125}$ NAI, Comcol I, 2844, Acting Commissioner of the Colony to the Chief Secretary to the government, Lagos, 2I May I 946.

${ }^{126}$ NAI, Comcol I, 2786, Letter from A. Izzett on the petition of the women's party, 23 Oct. 1946. ${ }^{127}$ Mba, Nigerian Women, 200. 
Table 3. Number of children passed through the hostels

\begin{tabular}{ccc}
\hline \hline & Girls hostel & Boys hostel \\
\hline I 943 & 340 & 345 \\
I 947 & $838(369$ child hawkers $)$ & $?$ \\
I 948 & 7 I6 (363 child hawkers $)$ & 300 \\
I 949 & $340(40$ child hawkers $)$ & 345 \\
I 956 & $?$ & 743 \\
\hline \hline
\end{tabular}

Sources: NAK, MSCW, I283, Report on social welfare service in Nigeria for I949; MSCW, I226, Report by Mr Chinn, Social Welfare Adviser to the Secretary of State, February I950; MSW, I 283 , Report on social welfare services in Nigeria for I 949. NAI, Oyo Prof, I 352, Juvenile Delinquency and its treatment, I 948; CO 554/2004, Annual Report on the Federal Prison Department, I956-7.

Table 4. Cases brought before Fuvenile Court of Lagos

\begin{tabular}{crc}
\hline \hline & Cases & Convicted of hawking \\
\hline I 946 & I ,200 & 668 \\
I 947 & I,062 & 742 \\
I 948 & I,352 & $?$ \\
I 949 & 928 & 303 \\
I 956 & I,436 & $?$ \\
\hline \hline
\end{tabular}

Sources: NAI, Oyo Prof, I352, Juvenile Delinquency and its treatment, I948; NAK, MSCW, I283, Report on social welfare service in Nigeria for 1949 ; CO 554/2004, Annual Report on the Federal Prison Department, I956-7.

prostitutes. ${ }^{128}$ Despite the protest, the Welfare Office and the Commissioner of the Colony kept the ordinance in force until the end of the colonial period. The immediate effect was a sharp increase in the number of female hawkers forced to pass through the girls' hostel ('Table 3) and of female hawkers brought before the juvenile court (Table 4).

The criminalization of young girls was predictable. Both the 1933 British and the I943 Nigerian ordinances encouraged greater intervention into the lives of young women and very young children on the grounds of 'moral danger'. The changing definition of the law had doubled the number of juvenile offenders in Nigeria in the I940s. Alan Milner, referring to Lagos in the early ig6os, also considers that 'there was for many years a preponderance of female offenders, as the largest single group of offences involved illegal street trading by young girls - virtually three-quarters of all juvenile crime dealt with'. ${ }^{129}$ As noticed by John Muncie, 'welfarism is just as capable of drawing more young people into the net of juvenile justice as it is of affording them care and protection'. ${ }^{130}$ The ordinance also made

128 'Social welfare service', Nigerian Daily Times, 26 Feb. 1948; West African Pilot, I 3 Apr. 1948, quoted by Mba, Nigerian Women, 224.

${ }^{129}$ Milner, The Nigerian, 352.

130 Muncie, Youth, 257. 
considerable work for welfare officers. Moreover, the diversity of the functions of the girls' hostel, particularly the examination and investigation of hundreds of street hawkers, weakened its main aim of rehabilitating 'maladjusted adolescents', as was noted in a latter report. ${ }^{131}$ 'Protection' lasted until the very end of the colonial period, and, by 1958 , the Social Welfare Department was dealing with over a thousand children a year. ${ }^{132}$ Yet, in criminalizing their activities, the social welfare service was missing its main target: the fight against organized prostitution and juvenile gangs.

Reducing hawking did not affect delinquency, as far as Nigerian newspapers were concerned. Denunciation of Faguda activities was still very strong after the war. ${ }^{133}$ Faguda Boys escaped the effects of the Ordinance because they were mainly males over i 4 years old. Moreover, market women, who witnessed the commission of thefts by Faguda, did not dare inform the police for fear of retaliation. ${ }^{134}$ By 1946 , the women even had to pay protection money to Faguda Boys, a system of racketeering that is still organized today by Area Boys against traders in Lagos Island. ${ }^{135}$ In focusing on the wrong target (street traders rather than organized gangs), the welfare service had saddled itself with the impossible task of controlling an increasing number of young people.

Youths placed in hostels were dealt with by welfare officers. Convicted juvenile offenders were often either put on probation (33 per cent of cases in the second half of the I940s) or committed to an institution, generally an Approved School ( 5 per cent). ${ }^{136}$ In I 956, the three Approved Schools (one for senior boys, one for junior boys and one for girls) accommodated 238 boys and 24 girls, all convicted by the Lagos Juvenile Court. All the children attended outside schools and were trained as artisans before their release. ${ }^{137}$ But for all the others, the central solution was repatriation to the family and generally to the countryside. It represented the introduction in West African colonies of measures of control already in existence in eastern and southern Africa. Faulkner started issuing repatriation orders during the war, but the creation of the Welfare Service and the Juvenile Court Police Force represented a real change in the policy of repatriation. ${ }^{138}$ Although there are no statistical data, indirect sources suggest that hundreds of boys and girls were repatriated yearly from Lagos ${ }^{139}$ ' with a ruthlessness which suggested

131 NAK, MSWC, I226, Report by Mr Chinn, Social Welfare Adviser to the Secretary of State, Feb. I950.

${ }^{132}$ Marris, Family, 64

133 'Activities of Jaguda Boys', Nigerian Daily Times, 22 Mar. 1946; 'Hooliganism in Lagos Streets', Nigerian Daily Times, I8 May r946; 'Undesirables in Ikeja Area', Nigerian Daily Times, 4 June I946; 'Incidence of crime in Lagos', Nigerian Daily Times, 2 I Aug. I946; 'Pickpocket activities in buses', Nigerian Daily Times, 3 Sept. I946; 'Police protection on the wane', Nigerian Daily Times, i6 July i 947 ; 'Curb this menace please', West African Pilot, 24 July i947; 'Lagos and hooligans', Daily Comet, i I Dec. 1947. $\quad{ }^{134}$ Fourchard, 'Urban poverty', 298-9.

${ }^{135}$ Momoh, 'The political dimension', i 86.

136 NAK, MSCW, i 226, Report by Mr Chinn, i 950.

${ }^{137} \mathrm{CO} 554 / 2004$, Annual Report on the Federal Prison Department, I 956-7.

138 NAI, Comcol I, 2796, Commissioner of the Colony to the Superintendent of Police, 3 July 1946.

${ }_{139}$ NAE, PR/X2, Social Welfare Services in the Western Region, Nigeria, July 1952. 
the English outdated settlement laws'. ${ }^{140}$ This control lasted until I $960 .{ }^{141}$ However, such a policy was probably not very effective in reducing the number of juvenile offenders for three reasons. First, a large number of boys returned to their home districts outside Lagos where there was no social welfare organization. ${ }^{142}$ Since little development had so far been undertaken in the neighbouring countryside, for young people there were few alternatives to migration to Lagos. Second, repatriation orders were not effective for hardened criminals who returned 'in disguise by changing their names, to the place where they have been refused residence'. ${ }^{143}$ Third, the policy proposed in Lagos was not followed by the other provinces, as Chinn pointed out on his visit to Nigeria in I949:

It is impossible to deal with the large number of young immigrants, who, from time to time, become destitute in Lagos and any attempt to do so raises the question of how far is it possible for a Colony Welfare Service to deal with the problems affecting other areas unless and until similar services are available in those areas. ${ }^{144}$

\section{CONCLUSION}

Juvenile crime and widespread juvenile street trading existed before the creation of the Welfare Service but were ignored or neglected. Juvenile offenders were not even an issue for a judicial and penal system that provided almost nothing specific for youth. What was new in the r940s was the idea that 'juvenile delinquency' had become an urgent problem to be dealt with and that the root causes of the problem could be eliminated in controlling the work and movements of young people. In proposing specific legislation, generally based on the British experience, social services and colonial officers intended to protect youth against the criminal influence of the street. However, by conflating real offences with an urban way of life (working and playing in the street), the Welfare Service included very different behaviours in the same 'delinquent' category. 'Thus, after having almost totally neglected the phenomenon in the r930s, the colonial administration passed to an overestimation of juvenile delinquency in including what would later be called the 'informal sector'.

The impact of such a policy towards youth should not be underestimated, for at least three reasons. First, it missed its main target by criminalizing poor children rather than dismantling juvenile gangs, even if Approved Schools prevented a minority of those dealt with by the Welfare Service from becoming hardened criminals. Second, colonial welfare policy influenced the

${ }^{140}$ Helen Judd, 'The human factor in Nigerian progress. The Oliver Twists of the towns', West Africa, 24 May 1952.

${ }^{141}$ NAK, MSCW, Joint Memorandum by the Ministry of Social Welfare and Ministry of Finance, control of beggars, 8 Apr. 1959.

${ }^{142}$ By 1952, there were only seven Young Farmers' Clubs in the Western Province organized by the Welfare Office and they were all based in the Ikeja Division. NAI, Comcol I, 248, Agriculture Officer to the Department of Agriculture, Western Region, 7 Apr. I952.

143 'Activities of Jaguda Boys', Nigerian Daily Times, 22 Mar. 1946. See also 'Expulsion of thieves', Nigerian Daily Times, I 5 Aug. I 945.

${ }^{144} \mathrm{NAK}, \mathrm{MSWC}$, I226, Report by Mr Chinn, 1950. 
first generation of African welfare officers, probation and police officers as well as the first generation of political leaders. Post-independence welfare services kept intact juvenile hawking regulations, the remand home system and repatriation orders, and new welfare services in Southern cities (Ibadan, Enugu, Aba, Onitsha) put similar institutions (juvenile courts, remand homes) and similar policies into place during the r 960 s. ${ }^{145}$ Third, such policies have contributed to the vulgarization of the nebulous concept of 'juvenile delinquency' even though changes in practices and legislation make it difficult to produce a consistent definition of what has actually constituted delinquency in Africa. International conferences organized in the r 950s - largely based on knowledge compiled by colonial officers, social welfare workers and sociologists since the I 940 - popularized 'juvenile delinquency' as a specific problem for social policy in Africa. Notions of the 'pre-delinquent child'146 and the maladjusted youth (jeunesse inadaptée), ${ }^{147}$ which included any youth likely to become delinquent, i.e. street traders, touts, beggars or the handicapped, arrived simultaneously (from the I 950 s to the I 980 ) and constituted another important element in the colonial heritage of criminalizing youth. Juvenile delinquency remains one of the idiomatic expressions of the Bibliothèque coloniale and, as far as the literature on youth and street children is concerned, it has not yet been decolonized.

145 NAE, x 245, Council of social service report, Aba Zone, 1965; Progress report on Onitsha Council of Social Service, I965. Offences against street trading regulations remained the most common cases dealt with by the Juvenile Court of Ibadan between I960 and I970 (39 per cent). Simple thefts accounted for only 28 per cent of cases. O. Oloruntimehin, 'Ibadan Juvenile Court Record Study (r960-1969)', University of Ibadan: Behavioural Science Unit, I97 I.

${ }^{146}$ Danièle Poitou, 'Délinquance juvénile et urbanisation au Niger et au Nigerie', Cahiers d'Etudes Africaines (I98I), 8I-3, I I I-27; Achille Mbembe, Les jeunes et l'ordre politique en Afrique noire (Paris, I985).

${ }_{147}$ Mamadou Dia Issa, L'exode rural ruine la campagne et fait affluer à la ville toute une population inadaptée (Dakar, ENAES, I 976); Seydou Diaw, Inadaptation sociale des jeunes au Sénégal, une problématique du développement économique (Marly Le Roy, I 978); Nessim Hazoref, Rapport sur la protection et la rééducation des jeunes inadaptés sociaux au Togo: méthodes et programmes d'action (Lomé, Ministère de la fonction publique du travail et des affaires sociales, I97I); Latif Fassassi, Approche sur l'inadaptation sociale des jeunes au Bénin et proposition pour une action de prévention (Marly le Roi, I97I); Sanogho Adama, 'Inadaptation sociale et traitement des délinquants au Mali' (Université de Paris 2, I 976). 